\title{
HASTANE IC̣ MEKAN TASARIMINDA MALZEME KULLANIMI
}

\section{Arș. Gör. Elif Özgen*}

Özet: İç mekan tasarımı çalışma alanı, belirlenmiş olan mekanın; işlevsel, pratik, estetik olarak ihtiyaçlarının karşılanmasına ilişkin bir çözüm arayışıdır. Mekan tasarımı; sanat ve bilimden beslenerek, oldukça geniş bir sahada, teorik ve pratik olarak gelişim göstermektedir. Yapının türü ve belirlenen tür için kullanıcı ihtiyaçları, inceleme sahasına göre mekan tasarımı konusu farklı uzmanlık alanlarına ayrılmaktadır. Yapı tipleri arasından özellikle sağlık mekanları; tıbbi müdahalenin gerçekleşmesi sebebi ile diğer yapı gruplarından farklılaşmaktadır. Sağlık sektörü için kapsamlı bir yapı bütününü içeren hastaneler ise; birbirinden farklı gereksinimleri karşılaması zorunluluğunu taşımaktadır. Çalışma konusunun sınırları; tıbbi pratik içermeyen ancak kullanıcıyı karşılayan, hasta, hasta yakını, personel gibi kullanıcı tiplerinin tamamını kapsayan, hastane genel mekanları olarak belirlenmiştir. Nitel araştırma yöntemi ve betimsel değerlendirme tekniği kullanılarak tümevarımcı bir analiz ile sağlık yapıları iç mekan bitiş malzemelerine ilişkin teorik bir altlık oluşturulmaya çalışılmaktadır. Belirlenen sınırlar çerçevesinde, tasarım pratiğine; yönetmelik koşulları ile teorik bilgilerin analizi ve yorumu ile mimari uygulamaya ilişkin literatüre katkı sağlanması amaçlanmaktadır.

Anahtar Kelimeler: Sağlık Yapıları, Tasarım, İç Mekan Tasarımı, Hastane ve Malzeme, Sağlık Yapıları Tasarımı.

\footnotetext{
*Hacettepe Üniversitesi, Iç Mimarlık ve Çevre Tasarımı Anabilim Dalı Email: elifozgen@outlook.com, elif.ozgen@hacettepe.edu.tr Orcid No: 0000-0002-8081-2097
} 


\title{
MATERIAL USAGE IN INTERIOR SPACE DESIGN AT HOSPITALS
}

\section{Res. Asst. Elif Özgen*}

\begin{abstract}
The working field of interior design is a pursuit of a resolution with respect to meeting the functional, practical, aesthetic needs of a pre-specified space. The design of a space displays a theoretical and practical progress in a wide field by being nourished through arts and science simultaneously. The type of a building and the user needs for a pre-specified type are classified into different fields of expertise according to the field of examination regarding space design. Among the building types, healthcare facilities are especially differentiated from other groups of construction since medical interventions are practiced is such places. Hospitals, however, which include a comprehensive holistic structure for medical sector, are required to meet the needs varying from one another. The limitation of this research subject has been identified as hospital buildings in general, which involves the user types such as patients, patients' relatives, staff, etc. to welcome the user but contain no medical practice. It is an attempt to create a theoretical background for the finish line interior materials of healthcare constructions by means of an inductive analysis through qualitative research method and descriptive assessment technique. Within the framework of this limitation identified, it is aimed at contributing to the literature with respect to design practice, conditions of regulations together with the analysis and interpretation of theoretical knowledge regarding architectural practice.
\end{abstract}

Keywords: Healthcare Facilities, Design, Interior Architecture, Hospital and Material, Healthcare Design.

\footnotetext{
*Hacettepe University, Interior Architecture and Environmental Design Email: elifozgen@outlook.com, elif.ozgen@hacettepe.edu.tr Orcid No: 0000-0002-8081-2097
} 


\section{Gíriș}

İç mekan tasarımı, yaratıcı uygulamalarla pek çok ortak noktası olan disiplinlerarası bir etkinliktir (Brooker ve Stone, 2011, s. 27). İç Mimarlık disiplini ise, yaratıcı uygulamaları bir sonuç olarak değerlendirmekte ve düşünsel süreçten faydalanarak, doğru gerekliliklerle kavramsal, kuramsal ve pratik çalışmaları içermektedir. Tasarım fikir ve uygulamaları için vazgeçilemeyecek tek unsur, insandır. Bu sebeple teorik olarak çalışma alanlarının inceleme sahaları zamanla daha belirgin hale gelmiştir. Başka bir deyişle, her alanda mekanı kullanan insanın gereksinimlerinin aynı olmaması sebebi ile, meslek uygulama ve akademik olarak çalışma alanlarında uzmanlıklar oluşmuştur.

Temel olarak mekan tasarım yaklaşımları, yapı tipi ve tasarım ölçeğine göre sınırlılıklara sahiptir. Çünkü ofis ve opera iç mekan tasarımlarının aynı olmayacağı gibi, iki örnekte konut iç mekanından farklı çalışma gereklilikleri içermektedir. Bu anlamda, sağlık yapıları da diğer yapı tiplerinden ayrışmaktadır. Sağlık yapıları içerisinde fiziksel olarak kapsamlı bir alanı tariflemesi sebebi ile "hastane" yapı ve mekanları, diğer sağlık yapı grupları için kapsayıcı nitelikte bir çalışma alanı sunmaktadir.

Hastane yapıları ise, son zamanlarda sağlık sektörünün genişlemesi ve sağlık mekanlarına ilişkin yaklaşımların kullanıcı odağına taşınması sebebiyle sıkça teorik ve pratik bir saha olarak karşımıza çıkmaktadır. Farklı bilim ve sanat dallarının ortak bir araştırma konusu olarak hastane, mimari anlamda; planlama aşamasında fonksiyonellik, düzen ve hijyen gibi unsurların odağında planlanma gereksinimini içermektedir. Hastane yapılarının insan odağında duyarlılıklarının; sağlık, güvenlik, duygusal ve psikolojik olarak karşılanma gereksiniminin yanı sıra özelleşmiş tıbbi ortamların bulunduğu yerlerde optimum teknik verim ve teknik doğruluk sağlama zorunlulukları da mevcuttur
(Ergenoğlu, Aytuğ, 2007, s. 44-50). Belirtilen zorunluluklar, üst başlık olarak ele alınabilecek hastane iç mekanları içerisinde de oldukça farklı sınıflara ayrışmaktadır. Çünkü günümüzde ameliyathane, hasta odası, giriş ve bekleme alanları, hasta muayene odası gibi farklı işlevler barındıran iç mekanlar için de uzmanlıklar ortaya çıkmaya başlamıştır.

Uzmanlık alanları yanında, hastane fiziksel koşulları ulusal yönetmelik ve kılavuzlarla kısitlanmaktadır. Teorik olarak edinilen bilgiler ve yönetmeliklerce tanımlı sınırlamalar içerisinde, düşünsel iç mekan tasarımını pratik edilmektedir. Tasarımcı için sürecin son ayağı olarak tarif edilebilecek aşama olan gerçekleştirme / yapma kısmı ise kullanıcının tasarımcının fikirlerine ilişkin ilk izleri taşımaktadır. Haliyle kullanıcı için en önemli kriterlerden birisi yapı elemanları olurken, tasarımcı için kullanıcıya ulaşan bir araç olarak görülmektedir. Çünkü özellikle hastane iç mekanlarını yaratma çabası, insan odaklı ve özne ile birincil nesneyi (yani malzemeyi) ilişkilendirme çabası içerisindedir. Bunu da özellikle duygusal anlamda gerçekleştirerek bağ ve aidiyete imkan tanımayı amaçlamaktadır.

Çalışmanın içeriği ve duyarlılığı tasarım kararlarını ve bahsi geçen insan odaklı tasarım yaklaşımlarına ait içerikleri yalnızca teknik olarak ele almaya yardımcı olabilecek büyük bir alanı tanımlamaktadır. Mekanı tanımlayan, yüzey alanları ve algıda kapladığı yer sebebiyle, malzemeler mekanı oluşturan yatay ve düşey düzlemler ile tanımlanmıştır. Mekansal olarak kısıt, hastanede genel kullanıma açık iç mekanlar için uygulamaya hazır bitiş elemanı alternatifleri üzerinden; duvar, zemin ve tavan yüzeyleri olarak belirlenmiştir. Genel mekanlar tanımı ise çalışma için; giriş, bekleme, danışma, hasta kabul ve sirkülasyon alanları olarak değerlendirilmektedir. 


\section{IC̣ MEKAN TASARIMI VE MALZEME}

Mekanın içinde özne olarak devamlı olarak deneyimleyen, insan; mekânı çeşitli bakış açıları ile incelerken, içinde hareket halinde ya da zaman geçirir durumdayken duyuları yardımıyla mekanı algılamaktadır. Mekansal algı; yalnızca hacimsel bir kavrama ve duyumsama olarak gerçekleşmektedir. Mekanın var olmasını sağlayan unsurların dışında insan algısını etkileyen malzemeye ilişkin, çeşitlilik, renk, doku, koku ve akustik değerler gibi etkenlerle kullanıcı için bir mekansal atmosfer gerçekleşmektedir (Seçkin, Yıldız, 2019, s.7-14). Yani tasarım; bütünsel bir yaklaşımı içermektedir. İç mekan tasarımında kullanılması planlanan tüm detaylar hem tek tek, hem de bütünsel olarak içerisinde değerlendirilmektedir. Bu sebeple malzemelerin nasıl kullanılacağına ilişkin veri pek çok parametrenin beraber değerlendirilmesi sonucu ortaya çıkmaktadır.

Mekan bileşenlerinin sağladığı sınırlayıcılık ve ayırıcılık etkisi, iç mekan kavramları için yüzeylerin nasıl bir araya geleceği sorunsalı ile karşılanması gereken ihtiyaçları beraberinde getirmektedir (Ching ve Adams, 2001). Yüzey elemanlarının oluşturulmasında kullanılacak malzeme seçiminde ise; kullanıcı gereksinimleri, çevreseli işlevsel, kültürel, ekonomik, estetik, sosyolojik, psikolojik ve çok daha fazla parametre bakımından, tasarım süreci üzerinde etkili olduğu düşünülerek tasarım sürecine ilişkin, veri olarak ele alınmaktadır.

Mekan yaratım sürecinin, var olabilmesinin en temel gereksinimlerinden biri malzemedir. Malzeme insana ulaşan niyetin ta kendisidir. Benzer bir bakış açısıyla, iç mekan tasarımı araştırma sahası, "mekan" nesnesini yaşanabilir, aidiyet kurulabilecek bir “yer”e dönüştürme çabası olarak karşılamaktadır. Nesne vasıtası ile tasarım fikri, yaşanabilir bir mekana dönüşme olasılığına sahip olmaktadır.
Tasarlanmış mekan yaratıcısı eliyle, kullanıcıdaki izi ön görmektedir. Değişik ilgi alanları, deneyimleri, tutumları, güdülemeleri olan kişilerde aynı malzeme, ilk görüşte farklı bildirimleri ve etkileri yaratabilmektedir. Soğuksıcak, pahalı-ucuz, yumuşak-sert, çekici-rahatsız edici, doğal-yapay gibi... Paslanmaz çelik yüzey ilk görüşte kimisi için pahalı olduğu izlenimi bırakırken, başka bir kullanıcı için soğuk bir his uyandırabilir (Yağl1, 2019). Malzemeler teknik anlamda ürünlere avantaj sağlarken, ürünlerin anlamlarını pekiştirmek üzere bir araç olarak da kullanılabilmektedir (Karana, 2006, s. 80-82). Seçilen malzemeye göre tasarımın dili farklı ifadeleri içerebilmektedir. Malzeme kullanımı ile mekanın tasarım yaklaşımı; yalın, masif, kaba, soğuk, hafif, derin, karmaşık gibi terimlerle ifade edilebilmektedir (Güzel, 2006).

Yapı malzemelerinin seçimi, uygulaması ve tasarım kararlarının başlı başına önemli bir parametredir. $\mathrm{Bu}$ anlamda yeni teknolojilerin kullanımı ile malzeme anlayışının değişmesi çok eski değildir. Devamlı malzemeye dair bilginin güncellenmesi, sürekli “yeni” olanın arayışı içinde olmamız ile ilişkilidir. Tarihsel süreçte malzemenin yapıda kullanımı, yaşanan değişikliklerle gelişmiş ve çeşitlenmiştir. Endüstri devrimiyle birlikte çelik, panel cam, betonarme gibi yeni malzemeler kullanılmaya başlanmış, 20. yy'da fizik ve kimya gibi temel bilimlerde yaşanan gelişim ile madde atomlarına, nöronlarına ayrıştırılmaya başlanmıştır. Madde üzerinde uygulanabilen iyileştirmelerse kimyasal değişiklikler vasıtasıyla istenilen özellikte malzemelerin üretimini mümkün kılmıştır. 21.yy'da ise nanoteknolojinin ortaya çıkışı ile istenilen özelliklerde; daha küçük, hafif ve akıllı malzemelerin üretilmeye başlanmıştır.

Günümüz teknolojisi ile, yapı malzemeleri içeriğinde, su tutmayan, spektrum seçici olan boya veya cam malzemeler, çizilmeye dayanıklı nanopartikül tabakaları gibi yeniliklerle 
malzemeler piyasada yer almaya başlamıştır (Yağl1, 2019, s.58). "Nano" malzemelerin kullanımı ile fosil bazlı enerji kaynaklarından faydalanma yaklaşımı yavaş yavaş azalmakta ve gelecekte oluşacak enerji problemlerini azaltmaya yönelik duyarlılık artmaktadır. Nanoteknoloji kapsamında geliştirilen "akıllı malzemeler" bu anlamda, dışarıdan gelen uyarılara cevap verme konusunda daha duyarlı, bir sistemin parçası gibi çalışmakta; çevresel faktörlere karşı ise; dayanıkl, duyumlu ve enerji konusunda daha az tüketici olması gibi özellikler taşımaktadır (Baktır, 2006, s.29-30). Tasarım bu noktada, zamanının malzemelerinin doğru kullanımını içermektedir. Bahsedilen doğru ise, pek çok koşulun optimumda çözümüne ilişkindir. Yani yapı tipi, kullanıcı, çevresel etmenler, ihtiyaçların karşılanması ve çok daha fazlasını kompleks olarak içeren bir çalışma olarak değerlendirilebilir.

Ayrıca insan ve mekan ayrılmaz, yaşamsal bir bütünü içermektedir. Maddesel etkileşim ancak nesne, kişi ve mekanlar arasında bağlantısız ve durağan bir ortamı oluşturmaya yetecek güçtedir. Halbuki insan ve mekan etkileşimi madde aracılığında değerlendirilecek bağ ile sınırlı değildir. Aksine insanın zihinsel bir örüntüyle, zaman ve mekanın ötesine yolculuğu mümkün kılabileceği düşünülmektedir.

\section{HASTANE IC̣ MEKAN TASARIMI VE MALZEME}

Sağlık yapıları her türlü hastanın, yaralı ve hastalık şüphesi olan insanların sağlık durumlarını kontrol ettirebileceği, ayakta veya yatarak, uzun veya kısa süreli olarak tetkik, muayene, teşhis ve tedavi ile rehabilite edildikleri modern, işlevsel yataklı kuruluşlar olarak tanımlanmaktadır. Hastaneler ise, büyük ölçekte ve kompleks olarak insanlara hizmet veren sağllk yapı tiplerinden biri olarak kapsamlı hizmet anlayışına sahiptir. Hastaneler yalnızca teşhis ve tedavinin gerçekleştiği bir yer olmaktan öte, sağlıkla ilgili tüm gelişmelerin izlendiği geçmişte çözümlenmemiş, gelecekte ise oluşabilecek tüm hastalıkları araştıran, irdeleyen, sürekli gelişme ve yenilenme çabasında olan sağlık kuruluşları olmuşlardır (Aydın, 2009, 1-12). Sağlık sektörünün temel bir ihtiyacı karşılaması ve bilim ve sanatın hayat kalitesinin artırılması için yeni tedavi yolları geliştirmeye çalışmasıyla sağlık mekanlarına ilişkin veriler devamlı olarak yenilenmektedir. Hastanelere ilişkin mekansal yaklaşım günümüzde, mekanın kendisinin de iyileştirici olması yönündedir. Bu yaklaşım ile malzeme konusunun öneminin artarak, kullanıcı ve mekan arasındaki etkileşime katkı sunacak önemli bir tasarım öğesi olarak görülmektedir.

Günümüzde artan nüfus ve teknolojinin gelişimiyle birlikte, hastanelerin sayısına paralel olarak kapasiteleri de artış göstermektedir. İnsan hayatının kurtarılması ve yaşam kalitesinin yükseltilmesi bu anlamda hastanelerin amaçları haline gelmektedir. Hastanelerin tedaviye yönelik çok yönlü işlevlerinin yanı sıra, her türlü sağlık gereksinimlerini karşılamaları gerekmektedir. Bir kamusal mekan örneği olarak hastaneler; kullanıcı sayısı fazla ve bitiş kullanımının yoğun olduğu alanlardır. Bu sebeple hastane iç mekanlarında malzemelerin aşınma ve yenilenme ihtiyaçları diğer yapı tiplerinden farklıdır ve ihtiyaç duyulduğu koşulda yenileme yapılması gereken bir koşulda bu ihtiyacın hızlı bir şekilde karşılanması gerekmektedir. Hasta ve hasta yakınlarını, çalışan sağlık personelini kısacası tüm kullanıcı tiplerini enfeksiyon riskinden uzak tutabilecek, dayanımı yüksek, estetik olarak ise genel tasarım yaklaşımına uygun malzemelerin seçilmesi gerekmektedir. Hastane iç mekanlarında enfeksiyondan korunmayı mümkün kılmak amacıyla çok amaçlı olarak tercih edilen malzemelerin yanında, özel olarak üretilen malzemelerin kullanımı da mekanın işlevine göre değerlendirilmesi gereken standartlar arasındadır. 
Hastane çok sayıda farklı işleve sahip mekanı bir arada bulundurmaktadır. Birimlerin işlevleri iç mekan tasarımlarının farklılaşmasını bir zorunluluk haline getirmektedir. Örneğin; cerrahi işlemlerin yapıldı ̆̆ı bir iç mekanla, hasta odalarının ve sağlık personelinin kullanımına ayrılmış mekanların gereklilikleri birbirinden farklıdır. Türkiye'de hastane iç mekanlarında kullanılacak malzemelerin standartları Sağlık Bakanlığı’na bağlı olarak belirlenmiş “Türkiye Sağlık Yapıları Asgari Tasarım Standartları 2010 Yılı Kılavuzu"nca uygulanmaktadır. Ayrıca dünya çapında oluşturulan tasarım kılavuzları bölgesel olarak uygulamaları sınırlandırmaktadır. Bu anlamda ulaşılabilir önemli kılavuzlardan bir diğeri de İngiltere ve Avusturalya’nın standartlarını Sağlık Bakanlığınca belirleyen Health Building Note General Design Guidance for Healthcare Buildings (HBN, NHS) (20132017 tarihleri aralığında güncellenmiş çok sayıda kılavuzdan oluşmaktadır. Türkiye’de dahil olmak üzere dünya çapında kullanılan çok sayıda yönetmeliğin 'NHS'nin verilerinden faydalandığı görülmektedir.) Kılavuzların ve yönetmeliklerin standartları incelenerek; sağlık yapıları tasarımında iç mekanda kullanılabilecek malzemelere ilişkin yaklaşımı aşağıdaki gibi özetlenmiştir.

- Aşınmaya dayanıklı

- Kolay temizlenebilir

- Suya dayanıklı

- Antiseptik malzemelerle temizlenmeye ve gida asitlerinden korunmaya elverişli

- Yangına dayanımlı ve tutuştuğunda zehirli gazlar yaymayan

- Malzeme bitiş ve birleşimlerinin temiz ve boşluksuz uygulanması (bu yolla böcek ve haşerelerden korunmak)

- Yoğun dokulu ve delikli yüzeye sahip malzemelerin kullanılmasından kaçınılması gereken malzeme kullanımları belirtilmiştir.

Çalışma teorik altlı̆̆ını, yukarıda belirtilen genel özellikteki zorunluluklar ile sınırlandırmaktadır.

Hastane mekanları çok yönlü yapısal gereklilikten ve işlev alanından bir araya geldiği için malzeme gereklilikleri farklılaşmaktadır. Mekansal öğelerin çok yönlü oluşu ve mekanı tanımlayan sınırlılıklar yaratması sebebi ile çalışma; duvar, zemin ve tavan yüzey malzemeleri olarak üç grupta ele alınarak, kullanılabilecek malzeme alternatifleri üzerinde yoğunlaşmıştır. Çalışmada belirtilen yüzey elemanlarının özellikleri ise, onların kabiliyetlerine ve özelliklerine ilişkindir.

İç mekanda kullanılan malzemelerin kullanımı, yalnızca tek yüzeyde uygulama ile sinırlı tutulmamaktadır. Yapılan inceleme malzeme içeriklerini yalnızca zemin veya duvar yüzeylerinde ele alınmış olsa da, bir malzemenin duvar ve zemin yüzeylerinin ikisinde de kullanımına engel teşkil etmemektedir. Örneğin; zeminde kullanılan bir malzeme uygun görüldüğü koşulda duvar yüzey kaplaması olarak da kullanılabilmektedir.

\subsection{Duvar yüzey kaplamalart}

Duvar mekanı taşıma, bölme ve yalıtma kabiliyeti olan düşey yapı elemanıdır. Hastane iç mekanlarında işlevsel bir takım gereksinimlerin karşılanmasının yanında, duvarın göz seviyemizce algılanan bir yüzey olması sebebiyle; görsel ve estetik açıdan gerçekleştirilecek uygulamalarda önemli yere sahiptir. Binayı, dış çevreden gelebilecek ses ve gürültü, 1sı değişikliklerine karşı izole etmesi, iç mekanı ise; farklı birim ve mekanlarda oluşabilecek ses ve 1 sı değişikliklerinin ihtiyaçları kapsamında kontrol edilebilirliğini mümkün kılmaktadır (Özdağlar, 2008, s.90-94). Ancak çalışmanın içeriğinde bahsi geçen bitiş malzemeleri, genellikle belirtilen koruyucu özellikleri kapsam dışı bırakmaktadır. Mekana göre ihtiyaç duyulan yalıtım çalışmaları, bitiş malzemesinden önce, ince işlere geçilmeden 

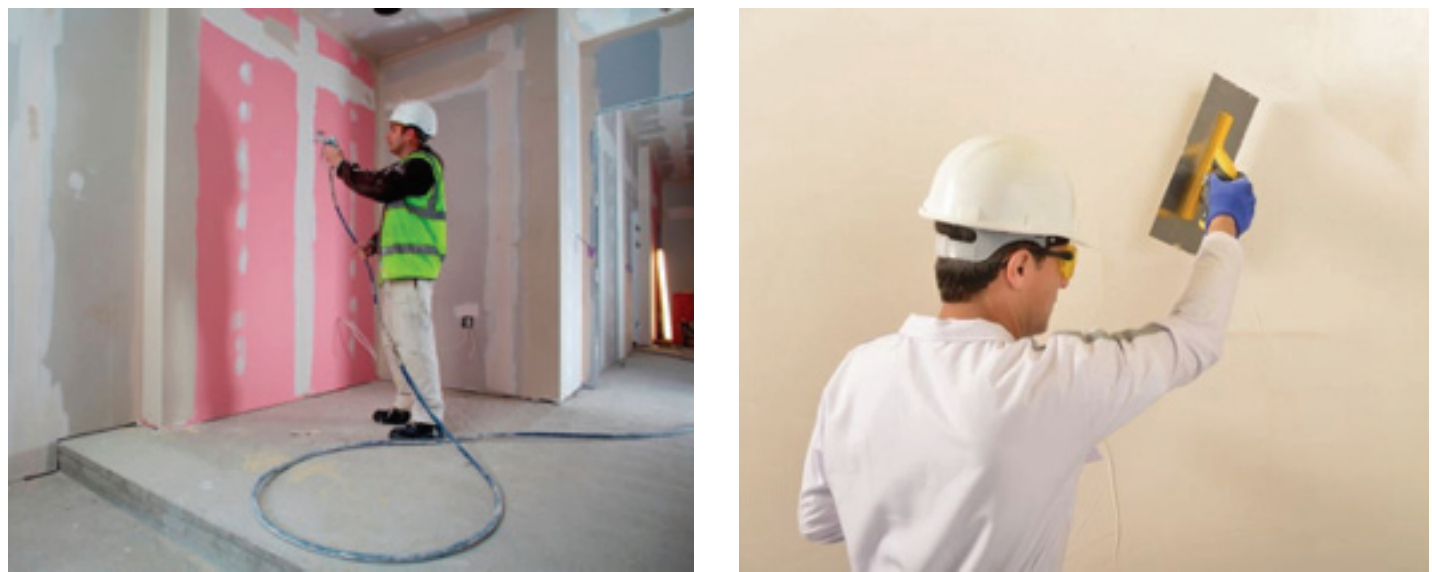

Görsel 1: Alçıpan üzeri püskürtme alçı sıva (solda) ve saten alçı (sağda) uygulaması (http1,13).

önce uygulanmaktadır. Yüzey/bitiş malzemesi olarak kullanılabilen yalıtıcı nitelikte malzemeler mevcuttur ancak sağlık yapılarında teknik gereksinimler hijyen sebebi ile olabildiğince gizlenerek yapıldığı için bahsi geçen malzeme kullanımları göz ardı edilmiştir.

Hastane iç mekanlarında duvar malzemelerinin toz, kimyasal ve buhar çıkaran yüzeylerden kaçınılması, parçalı malzemeler şeklindeyse büyük parçalar halinde kullanımı, gözenekli yapıda olmaması, kolay temizlenebilir ve antibakteriyel özellikte olması önerilmektedir (Kırbaş, 2012, s.25). Ayrıca, kaplamanın bakımının kolay olması, leke tutmayan özellikte olması da hastane mekanları için maliyetinin azalması anlamına gelmektedir. Aksi taktirde her aşınma ve yıpranmada malzemenin değiştirilmesi gerekmektedir. Bu durum ise mali açıdan yüksek olmasının yanı sıra, zaman anlamında kaybedilen ve çevreye etkisi anlamında yeniden tüketim anlamına gelmektedir. Özellikle ameliyathaneler, laboratuvarlar gibi steril mekanlarda ise; antibakteriyel malzemelerle bitiş yüzeyinin kaplanması gerekmektedir. Tesisat donanımları civarındaki duvar boyalarının, maruz kalacağ 1 yakın konumlu malzemeyi bozacak niteliği sebebiyle pürüzsüz ve suya dayanıklı olması beklenmektedir. (Karaman,2009, 28-33).

Hastane duvarlar kaplamalarında kullanılabilecek malzemeler aşağıda sıralanmıştır. Ancak bire bir olarak malzemenin uygulanmış halini görmeden, görsele bakarak bir takım malzemeleri birbirinden ayırmanın güçlügünü belirtmek gerekmektedir. Bu sebeple her malzeme için görselden faydalanılmamıştır. Bu durum çalışma kapsamında, zemin ve tavan malzemeleri için de benzerlik göstermektedir.

- Alçı Sıva: Genellikle malzemenin kendisi bitiş yüzeyi olarak kullanılmamakta, ek bir yüzey kaplaması ile uygulanmaktadır. Bakteri barındırabilir özelliktedir ve devamlı olarak iyi bir bakım gerektirmektedir. Üzerine gelecek yapı malzemesine göre niteliği ve içeriği değişkendir. Yangın geciktirici özelliğine sahip olmasının yanında duvar yüzeyinde küf, mantar oluşumunu engellemeye yardımcı olmaktadır. Uygulaması çeşitli şekillerde gerçekleşebilir, kolay uygulanabilir ve yenilenebilir özelliktedir (Görsel 1). Saten alçı uygulaması ile daha pürüzsüz düz bir yüzey elde edilebildiği için diğer çeşitlerine kıyasla hastane iç mekanlarında yaygın olarak kullanılmaktadır. Alçı sıva yerine, alçı levhaların kullanımı ve levha üzerine son katman malzemenin uygulaması da yapılabilmektedir.

- Latex Boya: Pürüzsüz bir kaplamadır bu sebeple uygulama öncesinde pürüzsüz bir yüzeye ihtiyaç duymaktadır. Su bazlı bir malzemedir ve hızlı kuruma özelliğine sahiptir. Ancak kolay 


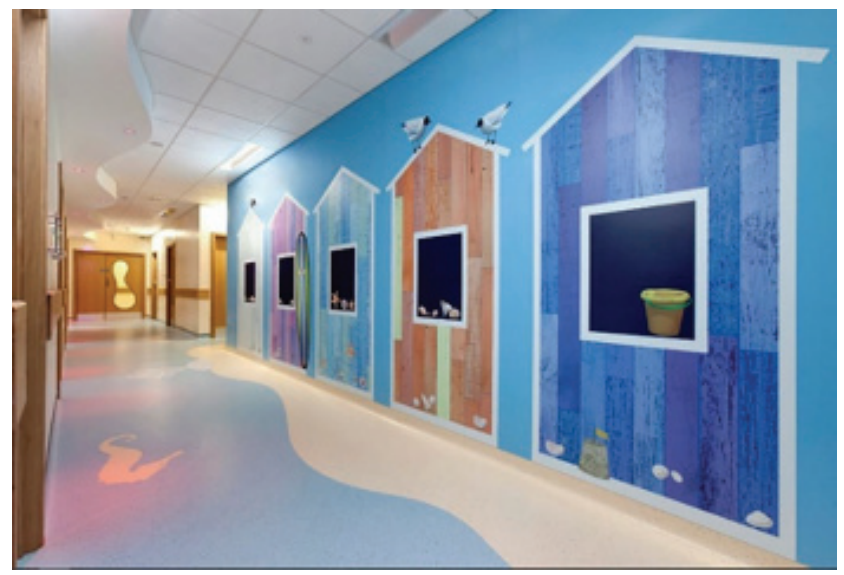

Görsel 2: Dijital Baskı Vinil Duvar Kaplaması, Salisbury District Hospital (http3).

yıpranabilen bir malzeme olması sebebiyle sürekli yenilenmesi gerekecek mekanlarda fazla tercih edilmemektedir.

- Yağlı Boya: Elastik, buhar geçirgen ancak su geçirmeyen özelliği ile yüzeyle bütünleşen bir yüzey kaplama malzemesidir. Latex boyaya kıyasla dayanımı daha uzun vadelidir ancak kimyasal yapısı sebebiyle zamanla sararma ve dökülme yapmaktadır. Uygulama ve kuruma aşamasında kötü koku yaymaktadır. Malzemenin kuruma süresi ise su bazlı malzemelere kıyasla uzundur.

- Oxicoat / Oxipaint: Siva ve boya malzemeleri üzerinde kimyasal olarak yapılan değişiklikler sonucu üretilen ekolojik yüzeyde kullanılan sıva ve mat görünüme sahip boya malzemeleridir. Duvar, tavan yüzeylerinde kullanıma uygundur. Oxicoat, içeriği ile kötü kokuları giderme özelliğine sahip sıvadır. Nem seviyesini dengeleme ve hava kalitesini artırmaya özelliğinin yanında rutubeti ve küfü engelleyici, yanmazdır. Nem dengesi ile vücuttaki kuruluk ve sonrasında oluşabilecek tahrişleri önlemeye yardımcı niteliktedir. Oxipaint boyanın belirtilen sıva ile beraber kullanımının; baş ağrısı, zihin bulanıklığı, halüsinasyon, mide bulantısı, adale seğirmeleri gibi olumsuz durumlar yaratan zehirli gazları önlemeye yardımcı olduğu belirtilmektedir (http2).
- Duvar Kağıdı: Dokulu/dokusuz, mat/parlak olarak pek çok renkte ve desende alternatifi mevcuttur. Dekoratif olarak kullanımının dışında, boyanabilen tipleri sağlık yapılarında sıkça tercih edilmektedir. Duvar kağıdının içeriği, malzemenin niteliklerini belirlemektedir. Kağıt, kağıt plastik gibi içeriklerin farklı oranlarda bir araya getirilmesi sonucu oluşturulmaktadırlar. Belirtilen farklılıklar, bitiş malzemesi olarak kullanılan duvar kağıdının; suya dayanıklı, kolay silinebilir, yıkanabilir ve antibakteriyel özelliklere sahip alternatifleri sağlamasında etkilidir.

- Seramik: Duvar yüzeylerine genellikle suyla temas edilen mekanlarda uygulanmaktadır. 10 yıldan uzun ömrü olması sebebiyle dayanımı yüksek bir malzemedir. Su geçirmez özelliği ile, kolay temizlenebilmesi sebebiyle tercih edilebilmektedir (Karaman, 2009: Rodermann, 1996).

- Dokuma Arkalıklı Vinil: Yırtılma, aşınma ve darbelere karşı dayanıklı, uygulaması kolay bir malzemedir. Renk ve desen alternatifi fazla, kolay temizlenebilen, büyük parçalı olarak uygulanabilecek, 6- 10 yıl arasında dayanım sağlayabilen nitelikte, sirkülasyonun fazla olduğu alanlarda da kullanıma elverişli bir PVC içerikli yüzey kaplama malzemesidir. Farklı ölçü, özellik, renk ve desende alternatifleri mevcuttur. Dijital olarak istenilen baskının yapılabilmesi mümkündür (Görsel 2). 


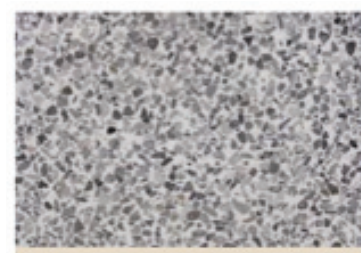

1 Terrazzo

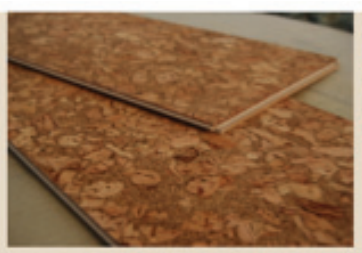

2 Mantar Karo

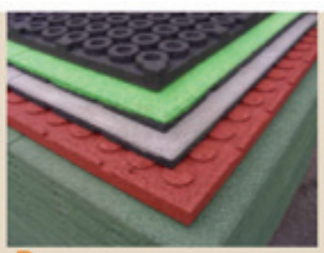

3 Kauçuk Karo

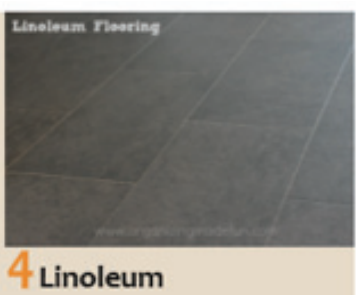

Linoleum

Görsel 3: Sert zeminlere örnek malzeme görünüşleri (http4, 5, 6, 7).

Sedye hareketlerinden dolayı duvar korumasinın arttırılması amaciyla koridor ve hasta odalarında, duvar yüzey kaplaması ile duvar koruma bandı olarak sıkça uygulaması yapılmaktadır.

Ayrıca duvar yüzeyleri ile ilişkili olarak, yapı elemanlarından süpürgelik kullanılmaktadır. Uygulamanın duvar yüzeyiyle aynı malzeme ile tamamlanması uzun süre sağlık yapılarında gerçekleştirilmiş bir uygulamadır. Zemin ve duvar yüzeyinin birleşim noktasında kullanılacak olan süpürgeliğin uygulama tipi, malzeme seçimi ve yüksekliği gibi görsel ve teknik unsurlar; belirtilen iki yüzeye göre şekillenmektedir.

Belirtilen malzemeler dışında geleneksel olarak faydalanılan; yüksek dayanımlı ahşap paneller, metal kaplamalar, kompozit malzemeler, dekoratif kırılmaya dayanıklı cam panel/mozaik/ tuğla, doğal taş (mermer, granit, traverten vb) malzemelerin uygulaması yapılabilmektedir.

\subsection{Zemin yüzey kaplamalart}

Yapılarda zemin kaplamaları, yatay yapı elemanları olan döşemelerin en son katmanını oluşturdukları için; uyuma, yürüme, yemek yeme, çalışma, temizlik gibi temel ve zorunlu ihtiyaçların tamamı için bu kaplama malzemesi üzerinde eylemler gerçekleşmektedir. Kullanıcı sürekli kaplama yüzeyiyle temas halinde olması sebebiyle sıcaklık, konfor, görsel etki, hijyen, yürüme güvenliği gibi nitelikler kullanıcıya kısa sürede ulaşmaktadır (Yılmaz, 2005, s. 4-21).

Hastane iç mekanlarında diğer yüzeylere kıyasla en sık kullanılan yapı elemanı olarak, zemin malzemelerinin kolay onarılabilir ve dayanımının yüksek olması beklenmektedir. Kullanıcıların gereksinimlerinin büyük çoğunluğunu zemin malzemeleri üzerinde karşılamaları sebebiyle de, işlevsellik anlamında da diğer yapı elemanlarına kıyasla zemin yüzeyi daha önemli hale gelmektedir. Ayrıca mekanın işlevine göre, ses geçirgenliğini azaltan akustik özellikli malzemelerin seçimi de gereklilikler arasında yer almaktadır. Döşeme malzemesinin üst yüzeyinin sedye ve yatak hareketlerini destekleyecek nitelikte olması da teşhis ve tedavi alanları için düşünülmesi gereken bir başka unsur olarak karşımıza çıkmaktadır.

Hosking ve Haggard (1999)'a göre; zemin yüzeyleri yumuşak ve sert olarak iki grupta incelenmektedir. Sert zeminler (Görsel 3); seramik karo, terazzo (epoksi uygulama çeşidi), mermer, granit, mantar karo, ahşap, kauçuk karo, epoksi, linolyum, vinil, pvc yumuşak zemin olarak ise yumuşak kauçuk, halı ve bazı PVC içerikli malzeme tipleri arasında belirtilmektedir.

- Pvc: Yüzey malzemesi olarak kullanılan PVC, aynı zamanda pek çok yüzey malzemesinin hammaddesi olarak da aynı ismi taşımaktadır. Aşınmaya karşı dayanıklı, bakımı ve temizliği kolay plastik esaslı bir malzemedir. Özel koruma ve hijyen kürleri ile bakım ve temizliği yapılabilmektedir. Köpük taban ile ses izolasyonu sağlarken, çukurlaşma dayanıklılığı ile de avantajlı bir yüzey malzemesidir. Ancak yanma riski sebebiyle; hastanelerde kullanılan kimyasal ve yanıcı maddelere karşı risk taşımaktadır. PVC malzeme yanmaz, tutuşmaz, alev almaz gibi farklı özelliklerde üretilebilmektedir, kullanılacak alana göre uygun niteliğin seçimi gerekmektedir. 

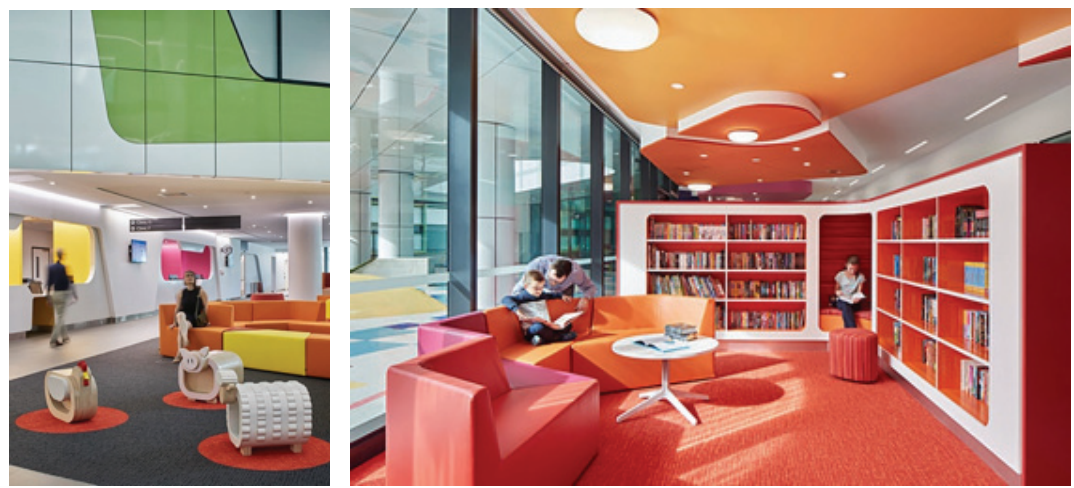

Görsel 4: Rulo halı kullanımı, Perth Children's Hospital, Avustralia (http9).

- Linolyum: Üretiminde tamamen doğal malzemelerden yararlanılmaktadır. Keten tohumu yağı, reçineler, kireç taşı, mantar, kurutucu ve pigmentlerin, jüt elyafın altlık üzerindeki bileşimidir. Yapısındaki bileşenler malzemeyi ateşe karşı dirençli kılmaktadır. Mantar altlık kullanımı ile amortisör ve ses emiciliği ile ses izolasyonu sağlamaktadır. Düşük alerjik ve antistatik (kir ve toz oluşumunu ve tutuşunu engelleyici) özelliktedir. Görsel olarak PVC'ye benzemektedir ancak malzeme duyarlılıkları farklıdır, ancak kolay ve hızlı uygulanması özellikleri ile benzerlik göstermektedir.

- Marmoleum: Marmoleum linolyum kaplamanın özel bir firma tarafından, daha dayanıklı hale getirilmiş bir versiyonudur. Çift koruyucu katmandan oluşan bir yüzey aracılığıyla uygulamadan sonra zemin üzerinde sadece rutin temizlik ve bakım işlemlerine ihtiyaç duyulmaktadır. Linolyum gibi doğal hammaddelerden üretilmektedir. Farklı renk ve desen alternatifleri ile rulo ve karo olarak 2 ayrı boyutsal alternatifi uygulanabilmektedir (http8).

- Epoksi: Hijyenik ve antibakteriyel olarak, birleşim ve bitirme detaylarının net olması gibi avantajları sağlamaktadır. Uygulama aşamasındaki, kimyasal içeriklerden faydalanılması sebebiyle uygulama alanı daralmaktadır. Mekanın nefes almasına izin veren bir yapıda değildir. Çok aşamalı bir uygulama yöntemi vardır, birbirine bağlı bu basamaklar süreci diğer malzemelere kıyasla daha uzun hale getirmektedir. Dökülme aşamasında kötü kokuya neden olan kimyasal bileşenler sebebiyle sağlık anlamında güvenilirliği uygulama alanlarını kisitlı hale getirmektedir (Karaman, 2009, s. 2833) (Yllmaz, 2005, s.25,26).

- Vinil Kaplama: PVC'den üretilen malzeme; aşınmaya karşı dayanıklı, kolay ve hızlı uygulama, düşük maliyet ve uzun ömürlü olması gibi avantajlara sahiptir. Desen ve renk seçeneği fazladır. Rulo ve karo olarak uygulanabilmektedir.

- Seramik: Yüksek ısı ile imal edilmesi sebebi ile ısı dayanımı yüksek bir malzemedir. Sırlanmış örneklerinde su geçirimi bulunmamaktadır ve piyasada satışa hazır ürünlerin neredeyse tamamı bu özelliktedir. Temizlik ve maliyet açısından ucuz olmasına karşın, kayma güvenliği konusunda yeterince güvenilir değildir (Aydın, 2000, s.7983). Hastanelerdeki sslak hacimlerde tercih edilebilir, ancak derz aralıklarının dar uygulanması hijyen anlamında daha olumlu bulunmaktadır. Fayans mozaik, gre mozaik, porselen karo gibi çeşit ve türleri bulunmaktadır.

- Halı: Yoğun olarak kullanılan mekanlarda, malzeme dayanıklılığının yetersiz olması sebebiyle uygulaması yaygın değildir. Antibakteriyel, yanmaz, antialerjik gibi farklı niteliklerde ürün çeşitlerine sahiptir. Standart dokuma ürünler temizlik sorunlarına ve kokuya sebep olabilmektedir. Rulo ve karo seçenekleri ile renk ve doku alternatifi fazla bir malzemedir (Görsel 4). 


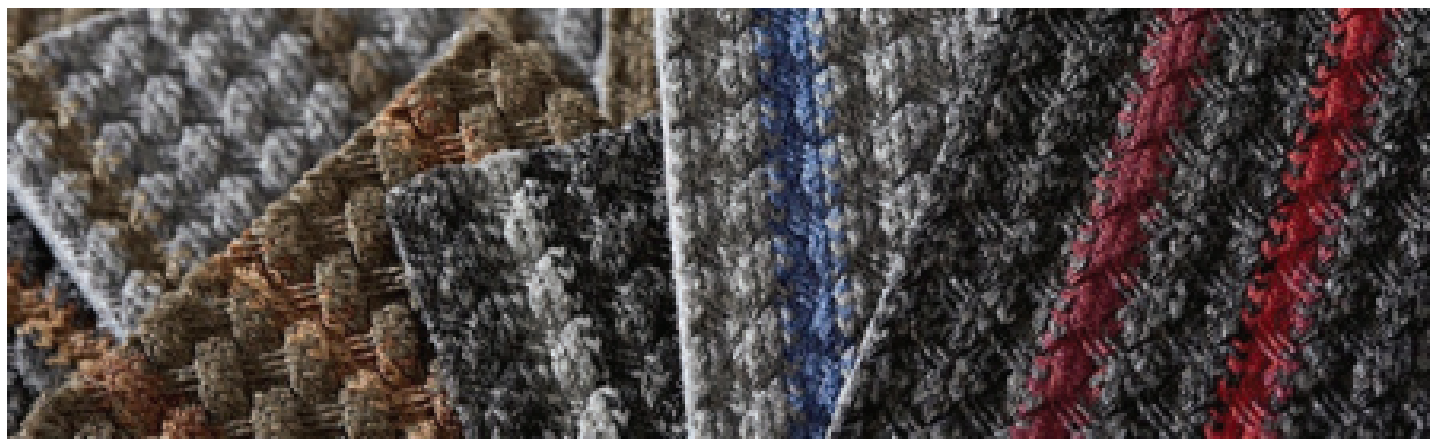

Görsel 5: Kompozit tekstil karo halı (Kinetex) örnekleri (http10).

- Kinetex: Kompozit materyalden imal edilen tekstil karo halı olarak üretilmektedir. Yumuşak zeminlerde ses yalıtımı sağlarken, sert zeminlere uygulanması ile dayanıklılık, kolay temizlenme, kir tutmama gibi özellikleri karşılayan bir üründür. 2 farklı yüzey dokusu, çeşitli renk ve desen alternatifi bulunmaktadır (Görsel 5). Pet şişe gibi geri dönüştürülebilmektedir ve $\% 60$ oranında geri dönüştürülmüş malzeme kullanılarak elde edilmektedir (http14).

- Ahşap: Yalıtım ve akustik olarak iyi bir yalıtım sağlamaktadır. Ancak çoğunlukla estetik özelliği nedeniyle tercih edilmektedir. Malzeme olarak ucuz olmamasına rağmen, deforasyonu hızlıdır, dayanımının yüksek olduğu malzeme çeşitlerinin sağlık yapıları için seçimi daha uygun bulunmaktadır. Ahşap zemin malzemesi olarak; masif, lamine ve laminant olarak uygulanmaktadır. Ahşabın dayanımının yüksek olması, (masif ahşap malzemede geçerliliği yoktur) malzemenin içeriğinde ve/veya koruyucu üst yüzey malzemesinde suya dayanımlı malzeme oranının yüksek olması ile ilişkilidir.

Yukarıda açıklanan malzemeler ile beraber belirtilen yüzey elemanları için mat/parlak yüzey alternatifleri çoğunlukla mevcuttur. Özellikle üzerinde hareket barındıran zemin yüzeyi için kaydırmazlık başka bir deyişle güvenlik önemli bir parametre olduğu için, malzemenin görsel olarak nasıl bir etki yarattığından çok gereksinimlerini doğru olarak karşılamasına daha büyük oranda önem verilmelidir. Bu anlamda özellikle ıslanması koşulunda parlak yüzeylerin kayganlığ 1 artırması sebebiyle yarı mat veya mat malzemelerin tercih edilmesi önerilmektedir.

Başka bir deyişle, sağlık yapıları iç mekanlarının sıkça temizlenme gerekliliği su ile olan teması artıracağından, kullanılması planlanan malzemenin karakterini belirtilen durum duyarlılığınca seçiminin gerçekleştirilmesi önerilmektedir.

\subsection{Tavan kaplamalart}

İç mekan oluşumunda tavan kaplaması, üçüncü boyutta sınırlamaları ve düşey düzleme etki eden farklılıkları ile önemli ölçüde etkiye sahiptir. Tavan yüzeyleri, duvar ve zemin yüzeyleri gibi görme ve dokunma açısından direk olarak kullanıcı ile bağ kurmamaktadır. Tavan uygulamalarının, mekanın boyutsal olarak kullanıcının üzerinde; yükseklik/alçaklık, ferahlık/darlık, rahatlık/resmiyet gibi psikolojik etkilerinin yaratılmasına imkan tanımaktadır.

Yapı bilgisi içerisinde, çeşitli tavan çeşidi mevcuttur. Bunlar; asma, kaset, yüzer, tekne gibi tiplerdir. Tavan kaplaması yapılması planlanan malzeme, tavan tipine göre seçilerek uygulanmaktadır. Diğer yapı elemanlarında olduğu gibi tavan uygulamalarında da sağlık yapılarında kullanılacak malzeme özellikleri önemlidir. Hastane tavan malzemelerinin; suya dayanıklı, kolay temizlenebilir nitelikte, gerekli olduğu koşulda tesisata kolay erişilebilecek ve ekonomik müdahale imkanı tanıyan malzemelerden seçilmesi gerekmektedir (Kuruçelik, 2009, s.51). 


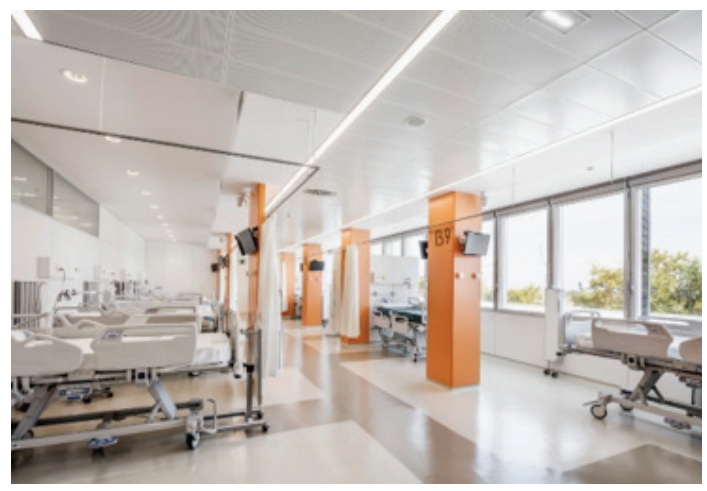

Görsel 6: Asma Tavan Kullanımı, Vall d'Hebron Hastanesi, İspanya (http11).

Malzemenin seçimini etkileyen en önemli değerlerden biri, tavan yüksekliğidir. Hastane yapılarında karmaşı bir teknik alt yapı gerekmektedir. Bu sebeple tesisatın gizlenebileceği ve kolay müdahale edilebileceği uygulamalardan faydalanmak yararlı olacaktır. Sağlık yapılarında tavanlar hem işlevsel hem de biçimsel açıdan öneme sahiptir. Tavanlarda bitiş malzemesi çok çeşitli olarak gerçekleştirilebilir, bu uygulamadan ziyaden seçilen materyale göre değişiklik göstermektedir.

Duvar ve zemin kaplamaları çalışma içeriğince, bitiş malzemeleri ve uygulama biçimleri ile anlatılmıştır. Ancak tavan kaplama da materyallerin özellikleri üzerinde durmak yerine tavan tipleri ve hangi materyallerin tercih edilebileceğine ilişkin verilerden faydalanılması istenmektedir. Bu durum, tavan uygulama tipinin, malzeme seçimi ile doğrudan ilişkili olması sebebiyledir. Ayrıca duvar ve zemin malzemelerinde özelliklerinden bahsedilen malzemelerin tavan malzemesi olarak kullanımı gerçekleştirilebilir.

- Asma Tavan: Tavan alt kotu ile konstrüksiyon arasında boşluk bulunmalıdır. Bitiş malzemesi olarak kullanılacak materyal konstrüksiyona monte edilmektedir. Hastane iç mekanlarında tavanlarda asma tavan uygulaması yapılarak, aydınlatma ve havalandırma tesisatları gizlenebilmektedir. Temiz, karmaşadan uzak ve estetik bir görüntü elde edilebilmektedir. Vektörel, taşyünü, karolam tipleri mevcuttur. Asma tavan uygulamasi; kumaş, plastik, alüminyum,

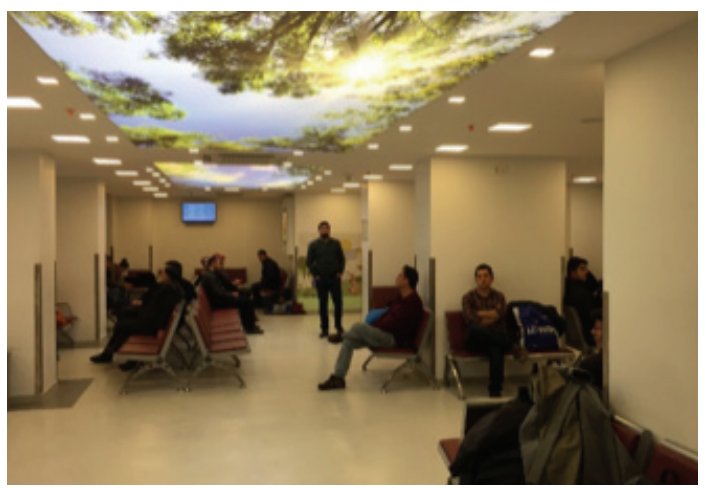

Görsel 7: Hacettepe Çocuk Hastanesi, Günlük Cerrahi Birimi Bekleme Alanı, Ankara (Kişisel Arşiv,2019).

ahşap, alçıpan veya sıva boya gibi malzemeler kullanılarak gerçekleştirilebilir. Sağlık yapıları iç mekanlarında; sistem araçlarının gizlenmesini olanaklı kılması sebebiyle tercih edilmektedir. Özellikle tıbbi uygulama gerektiren birimlerde, dekoratif uygulamalar yerine, kolay temizlenen, birleşim gerektirmeyen tek parça uygulamalardan faydalanılmaktadır. Asma tavan uygulaması ile; alçı sıva, latex boya, oxicoat/ oxipaint, PVC içerikli, metal ve ahşap malzemeler kullanılabilmektedir.

- Gergi Tavan: Her renk ve doku üzerine basılabilecek, yangına dayanıklı pvc mebran bir kumaş ile uygulaması yapılan bir asma tavan tipidir. Genellikle aydınlatma ile beraber kullanımı ile karşılaşılmaktadır. Bu sebeple alçı sıva ve boya uygulaması yaygındır. Montajı hızlı ve kolay yapılmaktadır. Özel mekanlardan çok genel mekanlarda kullanımı yaygındır (Görsel 7). Başka bir deyişle ortak, idari ve personel mekanlarında kullanıma uygun olmasına karşın, tıbbi işlemlerin bulunduğu mekanlarda uygulamasından kaçınılmalıdır. Dekoratif olarak aydınlatmaya vurgu yapan örnekler için, ek olarak dekoratif bir kaplamadan (ahşap, metal vb) kaçınılmakta ve odakta aydınlatmanın yer alması üzerine uygulama gerçekleştirilmektedir.

- Kaplama Tavan: Bitiş malzemesinin çeşitli yöntemlerle direkt duvara monte edildiği tavan tipidir. Bitiş malzemesinin tavan için özel olarak tasarlanmış olmasına ihtiyaç duyulmaz, montajı yapılabilecek ve düşme riski barındırmayan 

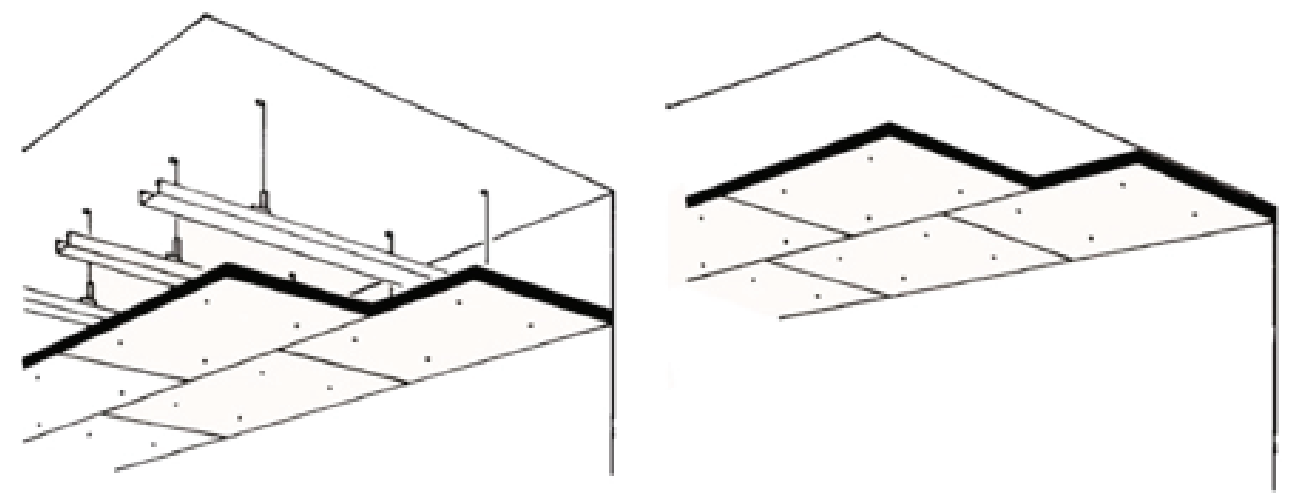

Görsel 8: Asma tavan (solda) ve kaplama tavan (sağda) tipi uygulama biçimleri (http12).

nitelikte çeşitli renk ve dokuda malzeme ile kaplanabilmektedir. Bu malzemeler duvar ve zemin malzemeleri arasında belirtilen; alçı sıva, boya, ahşap gibi malzemelerin yanında, alüminyum, çelik levha gibi metal malzemelerden de faydalanılabilmektedir. Ancak, tavan alt kotu ile arasinda müdahale edilemeyecek boyutlarda ilişki barındırması sebebiyle hastane genel mekanlarında yaygın olarak kullanılan bir tip değildir. Kullanımı durumunda, mekanın işlevi göz önünde bulundurularak kaplama tavan tipi ve yüzey malzemesi seçilmelidir.

\section{SONUC}

Sağlık mekanları kullanıcı sayısı ve uygulama / tedavi tipi / yatak sayısı gibi parametreler ile çok sayıda gruptan oluşmaktadır. Bu yapı tiplerinden toplumsal olarak hem ayakta hemde yataklı hizmet alabildiğimiz hastaneler yaygın olarak kullanılan sağlık yapısı olarak karşımıza çıkmaktadır. Teknik olarak pek çok zorunlu kısıtlamayı bünyesinde barındıran hastanelerin, mimari anlamda tasarım kriterlerinden faydalanılarak malzeme yaklaşımlarına öneride bulunulmaya çalışılmıştır. Çalışmanın temelini oluşturan hastane mekanlarına ilişkin standartlara ek olarak çevreye duyarlı, yerel malzemelerin kullanımını destekleyecek ve estetik faktörler düşünülerek malzeme kararlarının alınmasının faydalı olacağı düşünülmektedir. Geri dönüştürülebilir ve geri dönüştürülmüş malzemelerin tercih edilmesi, çevreye duyarlı olunması konusunda önemli farklar yaratabilmektedir. Ancak daha önce kullanılmış yapı malzemelerinden faydalanmak olumlu bir çevresel ve ekonomik etki yaratsa da hastaneler için, özellikle enfeksiyon riski bulunan tıbbi işlem içeren iç mekanlarda bu malzemelerden kaçınılmasının riski azaltacağı öngörülmektedir. Genel mekan uygulamalarında ise mekânsal parametreler göz önünde bulundurularak tercihi gerçekleştirilmelidir.

Çalışmada belirtilen kılavuz ve yönetmeliklerde, özellikle malzeme tarifinden kaçınmaktadır. Bu sebeple sektörel olarak büyük bir alanı oluşturan hastaneler için; mekansal gereksinimler yalnızca sınırlar gösterilerek işaret edilmektedir. Karşılaması gereken değerlerin içeriği, yapısal zorunlulukları belirtilmektedir. Bu yolla marka, model ve sektörel bir iz gösterilmesinden kaçınılmasının hedeflendiği düşünülmektedir.

Yapılan çalışmanın içeriğini oluşturan fikir, özellikle niteliklere uygun bitiş malzemeleri ile ilgili literatür bilgisini artırmaya yöneliktir. Ancak hastane içerisinde özel bir mekandan bahsedilmemiştir. Tasarımı planlanan iç mekanın işlevi doğrultusunda malzeme kriterlerince seçim yapılması ve diğer tasarım elemanları ile tasarımın gerçekleştirilmesi gerekmektedir.

Yapılan araştırma ile; uzun vadede malzemeye ilişkin değişikliğin önemli ölçekte olduğu, yakın zamanda ise yaklaşımın daha çok 
ekolojik malzemeler üretilmesine ilişkin olduğu gözlenmiştir. Malzemelere ilişkin hammaddenin çok farkllılı göstermediği ancak içeriğin değiştirilerek piyasaya sunulduğu sonucuna ulaşılmaktadır. Yani malzemenin ana materyalleri aynı kalsa dahi yeni kimyasal uygulamalar ve üretim alternatifleri ile yaklaşımın değiştiği görülmektedir. Her ne kadar uygulama aşamasında, bilinenin (sıkça uygulananın) dışına çıkma konusunda henüz çok girişken davranılmasa da yeni malzemelerin bilinirliği arttıkça uygulanma alanlarının da artacağ 1 düşünülmektedir.

Yapı malzemelerinin, ekonomik olarak önemli bir kaynak yarattığı gerçeği ile hem görünüş hem de içerik anlamında yeni ihtiyaçlar tanımlamaktadır. Yaratılan gerçek üstü ihtiyaçlar ile karşılanması zorunlu parametrelerin birbirine doğru biçimde ilişkilenmesi gerekmektedir.

Mekan sınırlarını yaratan duvar, zemin ve tavan yüzeyleri için uygulanabilecek, yönetmelik ve kılavuzlarla sınırlanan içeriklere uygun malzemeler, çeşitli kaynaklarca belirtilmiştir. Ancak en doğru bitiş malzemesi gibi bir seçim olamayacağ i için keskin ifadeler kullanılmamıştır. Hastane iç mekanında gerçekleşecek uygulamanın; içeriğine, organizasyonuna, işlevine, kullanıcısına vb. parametrelere ilişkin olarak değişiklik göstereceği için kaçınılmıştır.

Sonuç olarak; hastane iç mekanlarında kullanılacak malzemelerin; döneminin en güncel kılavuzunda belirtilen özellikleri karşılayacak nitelikte mekan tasarımını gerçekleştirmesi mevzuat gereği bir zorunluluktur. Tasarımc1 nitelikleri güncel olarak değerlendirmeli ve belirlenen alan için uygun bitiş malzemeleri ile işlevsel, estetik bir iyileştirici mekan oluşturmaya katkı sunmalıdır. 


\section{KAYNAKLAR}

- $\quad$ Aydın, D. (2009). Hastane Mimarisi İlkeler ve Ölçütler. Konya: Mimarlar Odası Konya Şubesi.

- Aydın, A. B. (2000). İç Mekanda Kullanılabilecek Duvar Kaplama Malzemelerin Akıllı Seçim Açısından Analizi ve Değerlendirilmesi. Yayımlanmamış Yüksek Lisans Tezi. İstanbul: İstanbul Teknik Üniversitesi, Fen bilimleri Enstitüsü.

- $\quad$ Baktır, S. (2006). Yapı Malzemelerindeki Teknolojik Gelişmelerin Mimari Biçimlenmeye Etkileri. Yayımlanmamış Yüksek Lisans Tezi. Ankara: Gazi Üniversitesi, Fen Bilimleri Enstitüsü.

- $\quad$ Brooker, G. ve Stone, S. (2011). İç Mekan Tasarımı Nedir?, (Çev. Z. Yazıcıoğlu Halu). İstanbul: Yapı-Endüstri Merkezi Yayinlari.

- $\quad$ Ching, F ve Adams, C. (2001). Çizimlerle Bina Yapım Rehberi. İstanbul: Yem Yayınevi.

- $\quad$ Ergenoğlu, A. ve Aytuğ A. (2007). Sağlı Kurumlarında Değişen Paradigmalar ve İyileştiren Hastane Kavramının Mimari Tasarım Açısından İrdelenmesi. YTÜ Mimarlık Fakültesi E - Dergisi, Cilt 2, Sayı 1, s. 44-63. https://www.megaronjournal. $\mathrm{com} /$ (Erişim Tarihi: 12.04.2020).

- Güzel, N. (2006). Yeni Malzemelerin Mimari Tasarıma Etkileri. 3.Ulusal Yapı Malzemesi Kongresinde sunulan bildiri.

- Hosking, S. ve Haggard, L. (1999). Healing the Hospital Environment: Design, Management and Maintenance of Healthcare Premises. London \& New York: E \& F N Spon,

- Karaman, S. (2009). Sağlık Yapılarında Konfor Koşullarının Săglanması Üzerine Bir Araştırma. Yayımlanmamış Yüksek Lisans Tezi. Kocaeli: Gebze Yüksek Teknoloji Enstitüsü.

- Karana, E. (2006). Ölümsüz Plastik, Ölümlü İnsan Ürün Tasarımında Malzeme Seçimi ve Malzemelerin Anlamları. Yirmibir Mimarlı Tasarım Mekan Dergisi, sayı 51, 80-82.

- Kırbaş, C. (2012). Hastanelerde Mimari-Mekanik Proje Tasarımı ve Uygulama Esasları. Tesisat Mühendisliği (TMMOB Makina Mühendisleri Odasi), Sayı 127-Ocak/Şubat, 15-30.

- Kuruçelik, G. (2009) Hastanelerin Acil Servis Tasarımında Bir Kalite Değerlendirme Modeli. Yayımlanmamış Yüksek Lisans Tezi. Trabzon: Karadeniz Teknik Üniversitesi, Fen Bilimleri Estitüsü.

- Ö̈zdağlar, E. (2008). Hastane Yapılarında İç Mekan Organizasyonu. Yayımlanmamış Yüksek Lisans Tezi. İstanbul: Haliç Üniversitesi, Fen Bilimleri Enstitüsü.

- Rodermann, P. A. (1996). Healthcare Design (Wiley Series in Healthcare and Senior Living Design). Edit. Sara O Marberry, Wiley.

- Seçkin, N. P. ve Yıldız, B. (2019). Mimaride Malzemelerin Algısal Farkllıklarının Değerlendirilmesi. İstanbul Sabahattin Zaim Üniversitesi Fen Bilimleri Enstitüsü Dergisi, Volume 1 Issue 2, 7-14.

- Yağlı, S. (2019). Teknolojik Gelişmelerin Etkisi ile Yüzeylerde Malzeme Kullanımı: Akıllı Malzemeler. Yayımlanmış Yüksek Lisans Tezi. Ankara: Hacettepe Üniversitesi, Güzel Sanatlar Enstitüsü.

- Yılmaz, A. (2005). Epoksinin Döşeme Kaplama Malzemesi Olarak Kullanılması ve Hastane Yapılarındaki Kullanımının Değerlendirilmesi. Yayımlanmamış Yüksek Lisans Tezi. İstanbul: İstanbul Kültür Üniversitesi, Fen Bilimleri Enstitüsü.

\section{- Internet Kaynakları}

- http1.http://www.paintinganddecoratingnews.co.uk/decorating-industry/fast-track-readymix-plasters/ (Erişim Tarihi: 03.03.2020).

- $\quad$ http2.https://www.seranit.com.tr/files/katalog/1455375969.pdf(Erişim Tarihi: 03.03.2020).

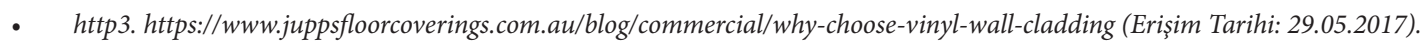

- $\quad$ http4.https://knittyschmitty.com/interlocking-outdoor-tiles.html (Erişim Tarihi: 02.03.2020).

- $\quad h t t p 5 . h t t p s: / / h e t t-c o m p a n y . r u / s h o p / p r o d u c t / p o d l o z h k a-p r o b k o v a y a-1$ (Erişim Tarihi:15.01.2020).

- $\quad$ http6.https://www.piramitsunger.net/kaucuk-zemin-karolari.html (Erişim Tarihi: 15.01.2020).

- $\quad$ http7. https://www.forbo.com/flooring/tr-tr/uruenler/pl28fo (Erişim Tarihi: 15.01.2020).

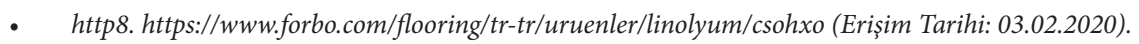

- http9. https://www.architonic.com/en/project/cox-architecture-perth-childrens-hospital/5106100 (Erişim Tarihi: 05.02.2020).

- http10. http://www.surface.ist/kinetex/ (Erişim Tarihi: 05.02.2020). 
- $\quad$ http11. toormix.com, (Erişim Tarihi: 28.05.2017).

- $\quad$ http12. https://festivalsalsacali.com/the-outrageous-fun-suspended-ceiling-detail-suspended-ceiling-pictures/photos-suspended-ceiling-detail-of-plaster-suspended-ceiling-tile-acoustic-a-14101-saint-that-great-suspended-ceiling/ (Erişim Tarihi: 03.02.2020).

- http13. http://furomahsap.com.tr/index.php/atiskan-yapi-urunleri/11-markalar/atiskan-yapi-urunleri/alci-urunleri/16saten-alcisi.html (Erişim Tarihi: 08.03.2020).

- $\quad$ http14. https://www.phenomenex.com/Kinetex/KinetexOrderNow (Erişim Tarihi: 11.03.2020). 